Compliment of

L. 2. Panmel

WEED

$\mathrm{OF}$

SOUTHINESTERN WISCOISIN

AND

國 SOLTHEASTERN MINNESOTA,

$\mathbf{B} \mathbf{Y}^{-}$

L. H. PAMMEL,

ST. LOUIS, MO.

SAINT PAUL, MINN.:

The Pioneer Press Company. 1887 . 



\section{WEEDS.}

or

\section{SOITHWESTERI WISCONSIN}

ANI

\section{SOUTHEASTERI MINNESOTA,}

BY

L. H. PAMMET,

ST. LOUIS, MO.

SAINT PAUL, MINN.:

The Pioneer Press Compayy.

1887. 



\title{
WEEDS OF SOUTHWESTERN WISCONSIN
}

\author{
AND

\begin{abstract}
SOUTHEASTERN MINNESO'TA.
\end{abstract}

\author{
A CONTRIBUTION TO THE LOCAL FLORA OF \\ LA CROSSE AND VICINITY.
}

By L. H. Pammel, St. Louis, Mo.

The term "weed" is used somewhat loosely, and often plants which are not troublesome are called weeds, and on the other hand certain plants which are showy are not (among the laity, at least), considered weeds, such as the common Corn Poppy, of Europe, Papaver rhceas. But any plant growing persistently where it is not wanted may be looked upon as a weed. One of the best definitions, and the one now generally accepted, is a "plant out of place." This definition includes everything which can possibly be called a weed, whether showy or not. The greater number of weeds do not have showy flowers, a few exceptions are the mustard, thistles, etc.

\section{PROLIFICACY OF WEEDS.}

The following figures are from Prof. W. R. Lazenby. (1) In Wild Parsnips the number of seeds per plant was from 4,834 to 19,000. A rather large plant of Curled Dock, Rumex crispus, 36,000. Shepherd's Purse, Capsella bursa pastoris, 62,500 to 77,500. The Burdock, Arctium lappa, had, the second year of its existence, 400,328. A single plant of Foxtail Grass, Setaria 
glaucu, had 19.499 seeds (fruits). Green Foxtail Grass. 46,041; Hedye, Mustard, Sisymbrium officinale, 36,685; Wild Mustard, Sinapsis nigra, L, 131,574. Common Plantain, 43,569.

\section{VITALITY OF THE SEEDS OF WEEDS.}

Seeds may retain their vitality for years, if not exposed to the air, and properly matured. Giradin sprouted beans that

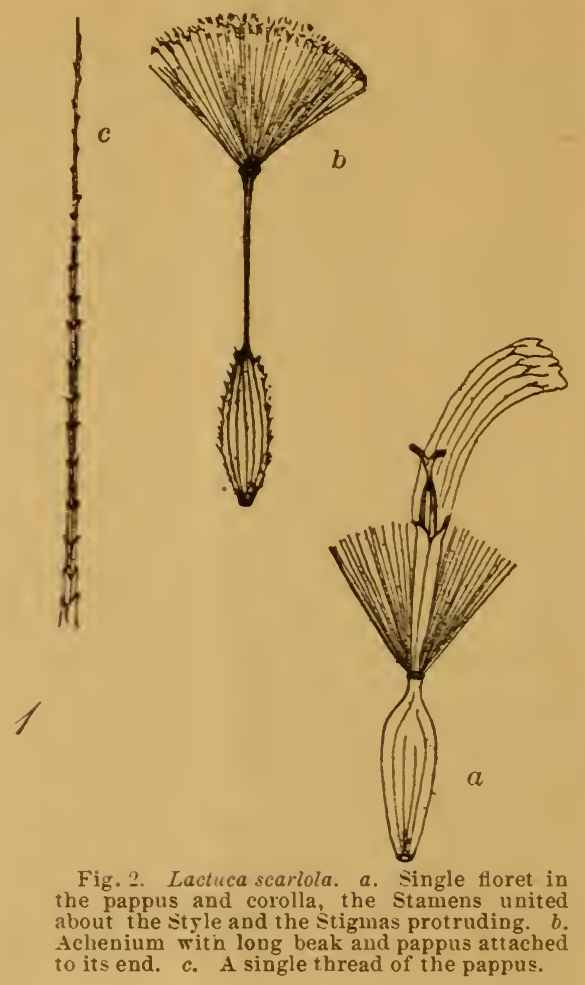

were orer a century old. In some experiments made by Haberlandt in 1861. the percentage of wheat which germinated was as follows: Those of 1850 and ' 51 , none germinated: 1854.8 ; 1855, 4: 1857. 73; 1858, 60; 1859, \&4; 1860, 96.

Oxrgen and moisture are the agencies which put a speed 5 limit to the duration of the germinative power of seeds.

Some of the rich bottom lands of this region, when in meadows for a few years, show no traces of the Great Ragweed. but when again cultivated. there springs up an abundance of this 
and other weeds. It is probable, in preparing the land for meadow, some of the seeds and fruits were deeply covered, and thus in a measure retained their vitality. Through eultivation the seeds and fruits have been turned up. The seeds of some

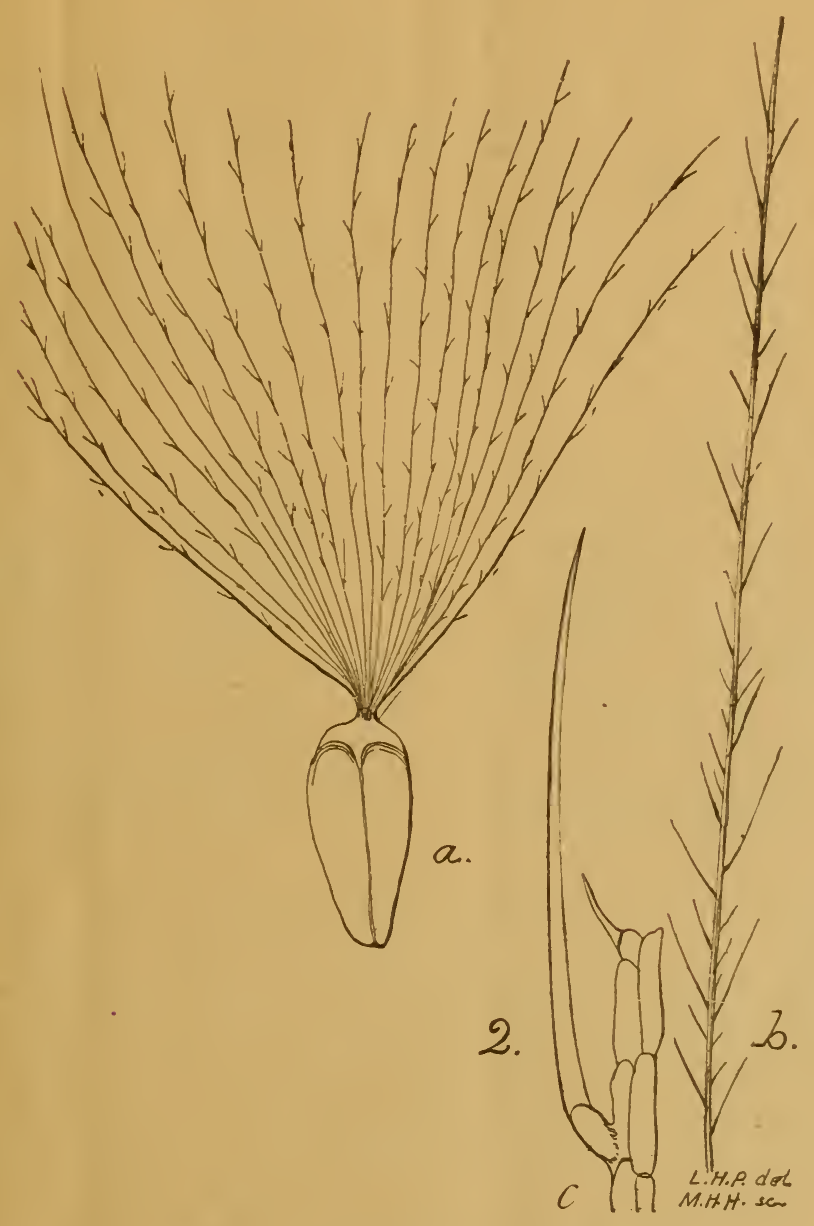

Fig. 2. Cnicus pumilum. a. Achenium with pappus. $b$. Single plumose thread. c. A part of $b$. more highly magnified.

orders differ greatly in their power of germination. The Le guminosie are capable of retaining their vitality for a long time, as the seeds are often provided with hard protective coverings (seed coats), which prevent decomposition. 
DISSEIIINATION OF WEEDS.

We can conveniently make two divisions:

1. Natural agencies-Wind, animals, water, snow. explosive properties of the fruit.

2. Where man is chiefly concerned-Impure seeds, railroads and other carriers, planting for ornamental purposes.

In most cases the fruits and seeds of our first dirision haye certain structures in form of burs, hairs, etc., which enable them to be disseminated.

In many of the compositie, the calyx, the outer set of the floral envelopes, is made up of a collection of fine, thread-like bodies, collectively called the pappus. In Prickly Lettuce, Lactuca scariola, $L$. The achenium (a one-seeded seed like fruit).

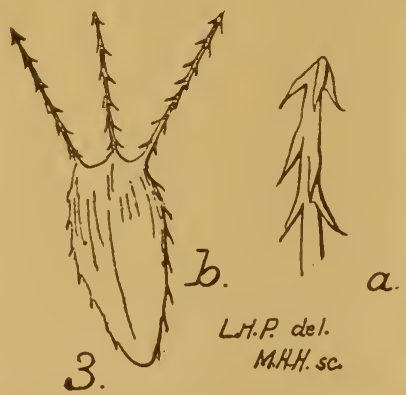

Fig. 3. Bidens connata $b$. Achenium with its awns barbed downwardly. a. One of the awns more highly magnified.

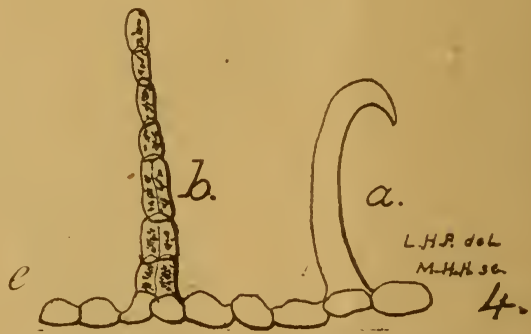

Fig. 4. Trichomes of Desmodium canescens. a. Hooked trichome. $b$. Ordinarr trichome. $e$ Epidermal cells magnified 122 times.

is carried out into a long beak bearing the pappus at its end. See Fig. 1. In another composite, The Pasture Thistle, Cnicus pumilum, Spreng. the pappus is made up of numerous fine and long threads which are plumose. See fig. 2. Such fruits are easily carried about by the wind, the akenes being in most cases light. The seeds or fruits disseminated by animals, at least among most of our weeds, are hooked and barbed. In Bidens connata the achenium bears three awns which are barbed downwardly. See Fig. 3. In Echinospermum lappula the small nutlets (forming burs which are not seeds but quarter portions of seed-like fruits $-6 \mathrm{~b}$ ), are covered with a double row of grappling organs. See Fig. 5. These burs easily fasten themselves to any passing object.

In Tick Trefoil, Desmodium canescens, DC., a troublesome roadside weed in the South, the pod breaks up into several transverse joints, and by means of the small trichomes (plant 
hairs). Which are hooked, as shown in Fig. 4, is enabled to cling to the fleese of animals and clothes of persons. anf thus it is often carried great distances. Birds aid also in disseminating of weeds, by the mud containing sereds which elings to their feet, and by eating of seerls, which pass through the digestive apparatus and are still capable of germinating. The water acts principally in a mechanical way by earrying the secels of weeds.

The writer has often seen Tumble-weeds, Pig-weeds. Thistle akenes on the surfice of the snow which were drifting before the wind, and when the snow melts in the spring these seeds and fruits are often carried still further by the water.

Certain fruits, Touch-me-nots, Imputiens, Woor Sorrels, $O x$ alis, ete., burst when the pod is tonched, thus scattering the seeds for several feet.

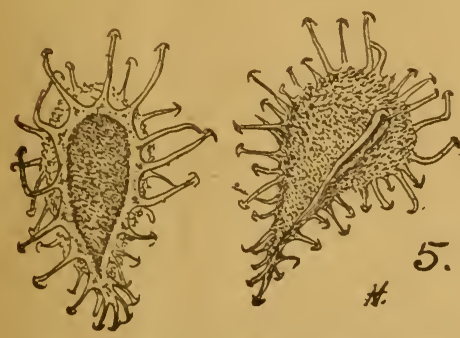

Fig. 5. Small nutlets of Echinospermum lappula, after Sudworth in Beal's Grasses

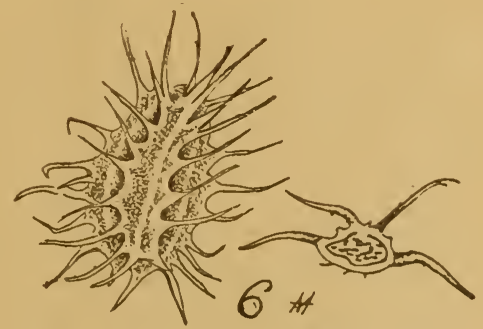

Fig. 6. Daucus curota. a. Whole fruit with prickles. b. Cross section, after iudworth in Beal's Grasses of N. A.

\section{IMPURITIES IN SEEDS.}

Prof. Lazenby found in Michigan Amber wheat sent out by the Department of Agriculture for 1SS4, the following impurities: Chess, Bromus seculinus, 9,248 seeds per bushel, an estimate made upon the amount found in one quart; Corn Cockle, Lychnis githago, 1,88s; Oat. Avena sativa, 160; Barley, Hordeum jubatum, 32; Snow Thistle, Sonchus, 32.

Many of our most troublesome weeds are introduced in this way. such as the Corn Cockle, Wild Oat, Avena fatua, ętc.

It is well known that railroads are a great factor in the distribution of pernicious weeds. One or two cases will suffice. Squirrel-tail grass, Horleum jubutum, was not known to occur in this region until last summer when it was found for the first time along the C.. II. \& St. P. railroad. Common Flax, Limum usitatissimum, $L$, is commonly found along railroads where the 
seeds must have fallen from passing freight cars, and hosts of others might be mentioned.

Years ago it was a matter of common observation when farmers hauled their grain long distances to some market that along the road could be found Chess, Corn, Cockle, etc. It can still be seen but in a less marked degree.

\section{MIGRATION OF WEEDS.}

Many of our most troublesome weeds are foreigners, as is made apparent from the table at the end of this list. Many have become so thoroughly naturalized that it is difficult to make a line of separation of the truly indigenous (native) and those naturalized. While we have added a large number of European plants, Europe has received trom us, such as the common Horseweed, Erigeron canadensis, the common Evening Primrose, Oenothera biennis, and Anacharis canadensis, a harmless North American water plant, said to be so abundant in England as to clog up canals. The number of American plants naturalized in Europe is. however. small compared with the number of European which have established themselves in this country. It may be due, as some one has suggested, to the greater plasticity of nature in the European flora or power of adapting themselves to circumstances such as our flora does not show. Some of our weeds which were at first ballast plants along the seaports. have moved westward. Prickly Lettuce, Lactuca scariola, which was for many years an adventive in Eastern New England. has since 1874 spread with remarkable rapidity, and is now found in many of the states east of the Mississippi river. Some western native plants have moved eastward and have become pernicious weeds. Solanum rostratum, a native of Kansas and Southwest, has traveled eastward and has been reported from New York. Of the less troublesome weeds Worm Wood, Artemisia biennis. Cone Flower, Rudbeckia hirta, are reported as common in the East and inclined to be "weedy."

In the arrangement of the orders and genera I have followed Bentham \& Hooker's Genera Plantarum. The nomenclature is that given in Dr. Gray's Srnoptical Flora of North America (Gamopetalae), Watson's Bibliographical Index to North American Botany (Pt. 1 Polypetalae), Botanical contributions by Sereno Watson and Dr. Gray and Vasey Grasses of the United States.

The introduced weeds are printed in Italics. 


\section{CRUCIEERAE.}

Sisymbrium officinale, Scop. Hedge Mustard.

Abundant in waste places and has become naturalized from Europe.

Brassica sinapistrum, Boissier. Yellow Mustard.

Frequently found in grain fields where it may become a great nuisance, as it is in Eastern United States and in Europe.

Nasturtium armoracia, Fries. Horseradish.

This perennial plant, first cultivated for its roots, which are well known as a condiment, has become thoroughly naturalized and is difficult to exterminate, though it spreads only by nonsexual means. It grows so profusely that all other plants are suffocated. It is European.

Capsella bursa-pastoris, Mœnch. Shepherd's Purse.

A common dooryard weed, abundant in waste places, roadsides, etc., flowering very early. It is a native of Europe, and has long been naturalized in this country and many other parts of the world.

Lepidium virginicum, L.

This, unlike the foregoing crucifers, is a native of southern United States. It is found along roadsides, in fields, in waste. places, and seems to adapt itself to various kinds of soil.

\section{CARYOPHYLLEAE.}

Lychnis githago, Lam. Corn Cockle.

A very common weed in grain fields. The large black seeds are very conspicuous ingrain. The seeds are roughened and very often, if the farmer is not careful. the larger seeds pass over with seed wheat. Cockle commonly matures earlier than wheat and oats, so that the seeds are liable to remain in the field.

The "screenings" of wheat, oats, etc., are largely used for feeding cattle, and as they are likely, and do, in a great many cases, contain the seeds of cockle and common Vetch or Tare, the farmer ought to be somewhat cautious in feeding his cattle. In some cases it is customary to boil or grind the "screenings;" in other cases it is fed raw, the seeds thus entering into compost, some passing the digestive apparatus without materially affecting the germinative powers of the seeds.

If it be preferable to feed "screenings" raw, the compost ought to remain till thoroughly rotted. 
This weed is also very troublesome in Europe. (Thaer, 1.)

The following two ought to be included, but neither of them is troublesome: Cerastium viscosum, L. Mouse Ear Chickweed. Stellaria media, Smith. Common Chickreed. Troublesome in Europe. (Thaer, 2.)

Saponaria vaccaria, L. Cow Herb.

Becoming abuhdant in grain fields in Houston County, Minn. The larger seeds are often found in seed wheat after cleaning. The smaller enter into "screenings."

\section{PORTULACEAE.}

Portulaca oleracea, L. Common Purslane.

This common garden weed with succulent stems and leaves is well known by almost ereryone who has had any experience in gardening. This plant ought not to be left in the field or garden when pulled up, as the severed parts readily develop into new plants by the formation of roots. It is also a well-known weed in Europe. Fendler found it wild in Texas and Nuttall on the Missouri. (Dr. Gray, 2.) Something rery near to the common purslane was found by Lindheimer (Englemann). It has the appearance, howerer, of being naturalized.

\section{MALTACEAE.}

Matca rotundifotia, L. Common Mallow.

Common around old dwellings, along roarlsides, etc. Found in similar places in Europe.

Abutiton avicennce, Gaertn. Indian Mallow.

It has spread quite rapidly. A few years ago, 1S52-S3, some straggling specimens were found along roadsides; now it is abundant in gardens and fields, especially where the soil is loose and of a loamy nature, or in loamy drifts. Last summer I found a field in the northern part of La Crosse Co., Wis., where it had completely taken possession. The plant is a native of Asia, and has probably mored northward along the Mississippi Rirer. Baron von Mueller reports it as occurring in Australia.

\section{GERANIACEAE.}

Oxalis stricta, L. Yellow Wood Sorrel.

Common in grain fields, not particularly troublesome. 


\section{LFGUMINOSAE.}

Ticia sativa, L. Common Vetch or Tare.

It is about the only really troublesome Leguminous plant we have, and, like Corn Cockle, is abundant in grain fields. The seeds are somewhat larger than Corn Cockle and smooth. In Europe it is largely used as a forage plant and greatly prized. (Kratt, 1.)

\section{ROSACEAE.}

Geum, Album, Gmelin. White Avens.

Becoming abundant along roadsides and borders of woods.

Potentilla norvegica, $\mathrm{L}$.

Common in waste places, fields and gardens.

Agrimonia eupatoria, L. Agrimony.

Common along roadsides, abundant in Europe, and troublesome in Southern Russia (Koppen), and especially as the fruits fasten themselves to the fleece of sheep. Baron von Mueller reports it as common in Australia.

Rosa blanda, Ait. Early Wild Rose.

Sometimes common in grain fields, where it causes amnoyance in harvesting.

\section{ONAGRARIEAE.}

Oenothera biennis, L. Common Evening Primrose.

In fields and waste places in a rather loamy soil. It is well known in Europe, where it has become naturalized.

Oenothera rhombipetala, Nutt. Evening Primrose.

Especially common on sandy prairies.

CUCURBITACEAE.

Sicyos angulatus, L. One Seeded Star Cucumber.

Along borders of streams and in moist places.

FICOIDEAE.

Mollugo verticillata, L. Carpet Weed.

Common in dry fields, an immigrant from the South.

UMIBELLIFERAE.

Conium maculatum, L. Poison Hemlock.

Not particularly troublesome as a weed, but from the fact that 
it and the following are very poisonous, they ought to be mentioned

Cicuta maculata, L. Water Hemlock.

Grows in marshes and swamps.

Peucedanum sativum, Benth. \& Hooker. Wild Parsnip.

Common in and about gardens, especially where Parsnip culture has been carried on, rapidly spreading.

Daucus carota, $L$. Wild Carrot.

In dooryards, and very abundant in dry fields. A weed in Europe.

\section{COMPOSITAE.}

Erigeron annuus, Pers. Tall Daisy.

Common in waste places, and in moist soil.

Erigeron canadensis, L. Horseweed.

In fields and waste places. Very abundant, especially in loose soil. The Tall Daisy and Horseweed are extensively naturalized in Europe. (Ratzeburg, etc.)

Erigeron strigosum, Muhl. Daisy Fleabane.

The plant is frequent in dry clay soil, but not as "weedy" as either of the above.

Gnaphalium decurrens, Ires. Common Ererlasting.

In old đ̄ry fields.

Inula helenium, L. Elecampane.

Thoroughly established in the northern part of Vernon Co., Wis., along roadsides.

Ambrosia artemisiæfolia, L. Common Ragweed.

Abundant along roadsides and fields, especially where the soil has been loosened.

Ambrosia trifida, L. Great Ragweed.

More troublesome than the preceding, especially common in rich bottom land. It is a coarse plant from eight to ten feet high, and when numerous growing, crops have little chance to. develop.

Xanthium canadense, Mill. Cockle-bur.

Along roadsides in loose sandy and gravelly soil. Becoming more numerous. Dr. Gray holds that what has commonly passed for Xanthium strumarium in this country is distinct, and should be referred to Xanthium canadense. Xstrumarium is sparingly naturalized in this country and occurs in barnyards and cultivated fields. In Europe it is troublesome, especially in Russia. (Koppen, 2.) 
Bidens frondosa, L. Common Beggar Ticós.

Along roadsides and in waste places.

Anthemis cotula, L. Mayweed.

Common in dooryards, along roadsides, and in waste placeson rather hard soil. preferably clay or loam. Also troublesome in Europe. (Thaer, 3 and Ratzeburgh, 1.)

Achillea millefolium. L. Yarrow.

In poor and dry pastures, and aloug roadsides. Its presences is an indication that the soil is rather poor. The plant is widely distributed across the continent of America. and also in Europe.

Chrysonthemum leuconthemum, L. Daisy.

Not common. In this region only a few loealities are known; ()ne in La Crosse, which is now obliterated, and in several other places a few straggling specimens. In eastern Inited States this weed is especially troublesome, but in Wisconsin and Minnesotal it is rare and somewhat local.

Tanacetum volgare, L. Common Tansy.

At one time largely cultirated as a garden plant, and now thoroughly naturalized. Along borders of fences and roadsides. This perennial is somewhat difficult to exterminate.

Artemisia biennis, Willd. Biennial Wormwood.

Common in waste places, dooryards and roadsides. Rapidly spreading eastward.

Arctium lappa, L. Burdock.

Along fences, in waste places in rich soil. The plant persists where once established, but does not spread as rapidly as many of our other weeds, as most farmers cut the plant off, not allowing it to mature its fruit.

Cnicus arensis. Hoffm. Canada Thistle.

Fortunately this plant is not as common here as it is in the (astern states. Mr. J. S. Harris reports it from Trempealeau Co., Wis., and in Upham's catalogue of The Flora of Mimnesota. it is reported from Fillmore Co. In July, 1SS6. I found it in the southern part of La Crosse Co., Wis., where it is said to have established itself some fifteen to tweuty years ago. Prof. Beal says: "Its course westward is likely to be checked by the fact that it has usually failed to produce seeds on the prairies." But it spreads freely below ground. It is a common weed of fields in Europe. Linnaeus, in his Flora Lapponica, considered it one of the greatest pests of the fields. (George Thurber, 3.)

Thaer recommends deep plowing, sereral times in a season. and after each plowing, to pull up the root stocks. Also that a 
good field of Lucerne, Medicago sativa or Onobrychis sativa, will destroy it. Prof. Beal (1) finds Red Clover a good weed exterminator.

Canada Thistle seems to be most abundant on loamy soil.

Cnicus lanceolatus, Hoffm. Common Thistle.

This is likewise a common weedy plant of Europe, and in this region very troublesome, at times especially, in loose and rich soil. It is a biennial and hence is much easier to deal with.

Cnicus pumilum, Spreng. Pasture Thistle.

Sometimes troublesome in dry rocky pastures.

Cichorium intybus, L. Succory or Chicory.

Has become established along roadsides, and proves a most pesistent weed where introduced.

Taraxacum officinale, Web. Dandelion.

Common everywhere, along roadsides, in pastures, etc.

Sonchus oleraceus, L. Common Sow Thistle.

Common in gardens and about dwellings.

\section{ASCLEPIADEAE.}

Asclepias cornuti, Decaisue, Common Milkweed or Silkweed.

Common in this section and often troublesome. A most pernicious weed in The Traverse Bay region, Michigan, and according to Prof. Beal (3) in many other portions of Michigan, especially in light soil. It is more commonly found in rich, rather loose, black sandy soil. It strikes root very deeply. and is difficult to exterminate on that account.

Asclepias tuberosa, L. Butterfly-weed.

Common on sandy soil and occasionally " weedy."

\section{BORAGINEAE.}

Cynoglossum officinale, $L$. Hound's Tongue.

Common along roadsides, La Crescent, Minn., and in dry pastures.

Echniospermum lappula, Lehm. Stickseed.

In gravelly soil, along roadsides, common. A troublesome weed in Southern Russia (Koppen), the burs fastening themselves to the fleece of sheep.

Echinospermum virginianum, DC. Beggar's Lice.

In woods, and borders of woods and along fences. 
(UNTOLVUACEAL.

Convolrulus sepium, I. Common Morning-glory.

The weed is troublesome in grain and corn fields. using the growing grain as a sllpport, often pulling it to the ground. The weed is one of the most diftieult to exterminate.

SULANACEAE.

solunum nigrum. L. ('ommon Xightshate.

In shady and waste gromel. common.

Duture stramonium, L. Jamestown Weed.

Locally it is known as Jimson weed, a corruption of .Jamestown.

It is becoming more plentiful. It is specially common in the streets of Brownsville. Mimn., and also found in a few places on the Wisconsin side of the Mississippi River. The plant is a native of Asia, but with us it has probably made its way north. ward along the Mississippi.

\section{SCROPHULARINEAE.}

Ferbascum thapsus, L. Common Mrullein.

Abundant in dry and old pastures, on rocky hillsides. Not difficult to exterminate as it is a biennial ; removing the young plants with a hoe will easily destroy it. Is occasionally "weedy" in Europe.

Linaria vulgaris. Mill. Toad Flax. Butter and Eggs.

Not troublesome, now and then found in neglected gardens, and here and there in the streets of cities. Said to have been widely distributed as a garden flower by the Department of Agriculture.

Scrophularia nodosa. I. Var. Marilandica, Gray. Figwort; Simpson's Bee Plant.

Somewhat weedy in rich soil and in damp places.

\section{LABIATAE.}

Teucrium canadense, L. Germander.

Along fences, hedges, etc., but is frequently found in fields so abundant as to do a great deal of injury to growing crops. As early as $18 \pm 6$ Darlington ( 2 ) found it to be somewhat of a troublesome weed in Pennsylvania.

Nepeta cataria, L. Catnip. 
Common along roadsides and fences, and occasionally in pastures in loamy soil.

\section{PLANTAGINEAE.}

Plantago major, L. Common Dooryard Plantain.

This and the following are common donryard weeds.

Plantago Rugelii, Decasine.

Occurring with the other. Plantago lanceolata. L.. has not been found in this region. In the South and East it is a troublesome weed. It has established itself at Madison. Wis.

\section{ANARANTACEAE.}

Amarantus retroflexus. L. Pigweed.

Common in manured soil, in fields, etc. It is a natire of tropical America. (?)

Amarantus albus, $L$. Tumble Weed.

Common in black sandy soil. In autumn it breaks off at the root and is driven before the wind. Naturalized from tropical America.

\section{CHENOPODIACEAE.}

Chenopodium album, L. Pigweed.

Common in rich and loose soil.

Chenopodium botrys, L. Jerusalem Oak.

Dry soil in streets of cities.

\section{POLYGONACEAE}

Rumex acetosella, L. Sheep's Sorrel.

In gravelly soil and in old fields. It is said that where this plant occurs, the soil is sour (Thaer, 5 ), and that an addition of lime or manure will drive it away. It is certain that the soil of Western Wisconsin and Southeastern Minnesota contains a great. deal of lime. The absence of lime can therefore hardly account for its abundance.

Rumex crispus, L. Curled Dock.

More common on high land, pastures, etc. The following. Rumex obtusifolius, L. Bitter Dock. is largely found in low meadows and pastures and is exceedingl $\boldsymbol{\Gamma}$ troublesome in pre- 
venting the growth of useful forage plants. Cattle will avoid it in all conditions. It is diffeult to exterminate, as it has a very long tap root and is a perennial.

Polygonum aviculare. L. Konotgrass.

A common dooryard weed.

Polygonum concolvulus, L. Black Bindweed.

Common in enltivated grounds and grain fields in loany soil.

Polygonum erectum, L.

Common in dooryards, etc.

Polygonum persicaria, L. Smartweed.

In waste places, and low grounds, rich soil.

Polygonum hydropiper, I. Common Smartweed.

Common in moist and wet grounds.

\section{EUPHORBIACEAE.}

Euphorbia cyparissias, L. Cypress Spurge.

Escaping from several cemeteries, La Crosse and North Bend, Wis., and La Crescent, Minn.

Euphorbia maculata, L. Creeping Spurge.

Common along roadsides, in dooryards, and on sandy soil.

\section{URTICACEAE.}

Urtica gracilis, Ait. Nettle.

Common along fences, hedges, etc.

Cannabis sativa, $L$. Hemp.

This weed is common along roadsides, especially in light loamy soil.

\section{GRAMINEAE.}

Panicum capillare, L. Old Witch Grass.

Common in sandy soil and cultivated fields.

Panicum crus-galli, L. Barnyard Grass.

In rich and wet soil, common.

Panicum sanguinale, L. Common Crab or Finger Grass.

Becoming numerous along roadsides.

Muhlenbergia mexicana, Trin.

Common along the borders of woods, fences, in damp clay and loamy soils.

Setaria glauca, Beaur. Fox-tail Grass. "Pigeon Grass."

A common weed in stubble, poor meadows, etc.

Setaria viridis, Beauv. Green Fox-tail Grass. "Pigeon Grass." 
More troublesome than the last in corn fields and cultivated fields generally.

Cenchrus tribuloides, L. Hedgehog or Bur-Grass; but better known as Sandburs.

On poor sandy soil along rivers, etc.

Avena fatua, L. Wild Oats.

In grain fields. Introduced a few years ago and somewhat troublesome. This species is widely diffused, in Australia. South America, etc. Employed for fodder in California and said to be very good.

Bromus secalinus, $L$. Chess or Cheat.

In grain fields especially noticeable in winter wheat or rye. Sometimes in meadows, but is not invaluable as a forage plant. Agropyrum repens, Beauv. Couch Grass or Quack Grass.

In grain fields, where it is a nuisance, but as a forage plant it is valuable.

Hordum jubatum, L. Squirrel-tail Grass.

It is probably only a waif. It is not a native here. In July. 1886, I found a small patch on the C., M. \& St. Paul R. R. near La Crescent, Minn.

Table showing origin of weeds.

\begin{tabular}{|c|c|c|c|c|c|c|}
\hline ORDERS. & Eu. & U.S. & Eu.\&U.S. & Trop. Am. & Asia & Total. \\
\hline Cruciferae...... & 4 & 1 & & & & 5 \\
\hline Caryophylleae ........................ & 4 & .. & & & & 4 \\
\hline Portulaceate ......................... & 1 & .. & & & & 1 \\
\hline 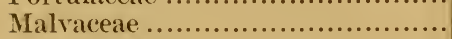 & 1 & & & & $\dddot{1}$ & 2 \\
\hline Geraniaceae ..... & & 1 &. & & & $\tilde{1}$ \\
\hline Leguminosae........................ & 1 & $\ldots$ & & & & 1 \\
\hline Rosaceae ............................ & 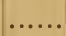 & 2 & $\dddot{2}$ & & & 4 \\
\hline Onagrarieae ............................ & 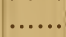 & 2 & $\ldots \ldots$ & $\cdots$ & & $\therefore$ \\
\hline Cucurbitaceae .......................... & .. & 1 & $\cdots$ & $\cdots$ & & $\tilde{1}$ \\
\hline Ficoideae.............................. & .... & 1 & 阳, & . & & 1 \\
\hline 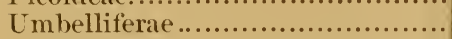 & 3 & 1 & & & & 4 \\
\hline Compositate .......................... & 10 & 9 & 1 & & & 20 \\
\hline 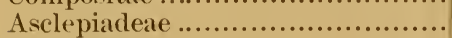 & ...... & 2 & & & & $\therefore$ \\
\hline Boraginease ........................... & 2 & 1 & & & & 3 \\
\hline Convolvulaceae ....................... & ...... & ... & 1 & & & $\ddot{1}$ \\
\hline Solanaceae .............................. & $\begin{array}{c}\cdots \\
1\end{array}$ & $\cdots$ & . & 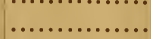 & 1 & 2 \\
\hline 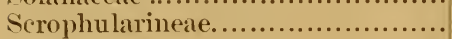 & 2 & $\dddot{1}$ & .. & & & $\tilde{3}$ \\
\hline Labiatae.............................. & 1 & 1 & $\cdots$ & & & 2 \\
\hline 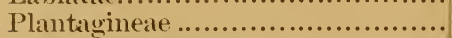 & 1 & 1 & $\cdots \cdots$ & .. & & $\tilde{2}$ \\
\hline tacear ...................... & $\ldots \ldots$ & ... & .............. & 2 & & 2 \\
\hline Chenopodiaceac................. & $:$ & & n............. & & & $\tilde{2}$ \\
\hline Polygonaceate........................ & $\overline{5}$ & $\ldots$ & 3 & & & 8 \\
\hline Euphorbiaceae....................... & 1 & 1 & & & & $\because$ \\
\hline Urticaceae............................. & 1 & 1 & & & & $\tilde{2}$ \\
\hline Gramineae .......................... & 6 & 4 & 1 & $\ldots \ldots$ & & 11 \\
\hline Totals... & 46 & 30 & 8 & 2 & 2 & 88 \\
\hline
\end{tabular}


Of the so weeds repiresented in this list, ff are European, and 30 of Ameriean origrin, one-thint of which come from the compositate, the most troublesome of our weeds and almost one-fourth of the entire list are members of the compositale.

The following are some of the important papers and works on the subject which have been consulted:

Arthur. Prof. J. C.

th and 5 th Ammal report of the N. Y. Agricultural Experiment Station, pages 262 and 298.

BEAL. Prof. W. J.

Grasises of North America (1) Vol. 1. p. $219 ;(2)$ p. 235;(3) p. 222 figures the seeds and fruits and has appended some remarks concerning the common weeds affecting the meadow. pp. 100, 224, 273.

Cla YPOLE, E. W'.

On the migration of plants from Europe to America with an attempt to explain certain phenomena connected therewith.

(3) Report of the Montreal Hort. Soc., 1877, p. 70.

D.RLINGTON, WM.

American Weeds and Useful Plants. Revised by George Thurber, (1) p. 199, (2) p. 241.

Dimitrievicz, Nicol.

Wie lange bewahren die Samen unserer Culturpflanzen ihre Keimfähigkeit. In Haberlandt's Wissenschaftliche Untersuchungen, etc.

Exglemint, Dr. George.

In Plantæ Lindheimerianæ, p. 154.

GraY, Dr. Asd.

Darwiniana.

(1) Am. Naturalist, Burs in the Boarage family. Vol. X, 1876 , p. 1.

(2) Am. Jour. of Sc. Vol. XXV, p. 253, and Vol. XXVI, p. 138.

HABERLANDT, Dr. G.

(1) Wissenschaftlich-pracktische Untersuchingen auf dem Gebiete des Pflanzenbaues.

(2) Wiener Landw. Zeitung, 1873, p. 126.

IhNe. Dr. Egon.

Studien zur Pflanzengeographie; Verbreitung von Xanthium strumarium und Geschichte der Einwanderung ron Xanthium spinosum.

KA BsCH, Dr. WVilhelir.

Das Pflanzenleben der Erde. 
KOPPEN, FR. TH.

Zur verbreitung des Xanthium spinosum L., besonders in

Russland, nebst kurzen notizen über einige andere Un-

kräuter Süd Russlands, p. 36, (2) p. 35.

Kraft, Dr. Guido.

Pflanzen Baulehre. (1) p. 76 and 189.

In this work are enumerated the principal weeds, with figures of fruits and seeds of many of the troublesome weeds in the fields and gardens of Germany.

LAzENBY, Prof. W. R.

Report on Weeds, Ohio Agricultural Experiment Station, 1884 and 1885. (1) 1884 , p. 158 . (2) 1885 , p. 185.

Weedy plants of Ohio. In.

Proceedings of the 7th annual meeting of the Society for the

Promotion of Agr. Science, 1856.

Martixs, CH.

Experience sur la Persistence de la vitalité des Graines

flottant a la surface de la Mer.

MUELLER, BARON VON.

Systematic Census of Australian Plants.

NobBe, Dr. F.

Handbuch der Samenkunde.

Likewise he figures the fruits and seeds'present as impurities in various seeds, especially those affecting the agricultural seeds of Germany.

RatzeburG, Dr. J. T. C.

Die Standortsgewächse und Unkräuter Deutschlands und

Schweiz. Berlin, 1859. (1) p. 59.

SCRIBNER, Prof. F. L.

Weeds of Maine. in Agriculture of Maine, 1869, p. 239.

SEYMour, Prof. A. B.

Weeds mentioned in weed law of $1881-85$, Wis., and several other weeds. Report of Wis. Agricultural Experiment Station for 1885 .

STURTEVANT, Dr. E. L.

First annual report of $\mathrm{N}$. Y. Agricultural Experiment Station, p. $S 6$.

THAER, Dr. Albrecht.

Die Landwirthschaftlichen Unkräuter; 24 chromo-lithographic plates. (1) p. 9, Taf. IV. (2) p. 10, Taf. V. (3) p. 14.

(4) p. 8, Taf. IV. (5) p. 11, Taf. VI.

UPHAM, WARREx.

Flora of Minnesota.

Shaw School of Botany, St. Louis, Mo., April, 1887. 

